\title{
RESENDE, Daiane Carnelos. Elementos decisivos na construção da posição e ação política de Roberto Requião de Mello e Silva. Jundiaí: Paco Editorial, 2014. 232 p.
}

\author{
Natália Cristina Granato ${ }^{1}$
}

- Enviado em 27/07/2015

- Aprovado em 28/08/2015

Poucos políticos brasileiros ficaram tanto tempo no comando de um estado da federação na história recente do Brasil. Roberto Requião de Mello e Silva é um caso que permaneceu três legislaturas no governo do Paraná, doze anos ao todo. Sua trajetória na política vem desde a década de 1980, na redemocratização, na qual se elegeu deputado estadual em 1982. Desde então, ocupou a prefeitura de Curitiba, o Senado Federal e os já citados mandatos de governador. Essa trajetória ascendente e complexa é analisada no livro de Daiane Carnelos Resende "Elementos decisivos na construção da posição e ação política de Roberto Requião de Mello e Silva", publicado em 2014, resultado de sua dissertação de Mestrado em Sociologia pela Universidade Federal do Paraná, defendida em 2007. Requião é um político que chama a atenção pela sua imagem, oratória e estilo de governo. A análise feita pela autora debruça-se sobre a trajetória social e política de Roberto Requião entre os anos de 1982 e 2006, "atentando-se, sobretudo, aos elementos que influenciaram em sua ação e prática política” (p.19). Tais elementos incluem a análise de suas origens familiares, importantes na construção do seu habitus e da sua vocação, juntamente com suas relações com grupos políticos do Paraná e seu partido, o PMDB. A análise é feita em 4 capítulos.

No capítulo 1 "Perspectivas teórico-históricas para a construção de uma trajetória política", Daiane Resende se utiliza de importantes conceitos da sociologia das trajetórias, sobretudo de Pierre Bourdieu, como habitus, campo político e capitais. Complementando tal análise, a autora reflete sobre liderança, autoridade e poder político dialogando com autores como Maurice Duverger, Orazio Petraca, Nicos Poulantzas, Harold

${ }^{1}$ Graduada em Ciências Sociais pela Universidade Federal do Paraná. Mestranda em Sociologia pela Universidade Federal do Paraná. Endereço eletrônico: nataliagranato@ hotmail.com. 
Lasswell e Max Weber. A partir dessas bases teóricas, Resende inicia suas reflexões sobre a trajetória política de Roberto Requião, que inicia sua carreira no contexto da redemocratização do Brasil, no qual o país estava saindo de um regime autoritário, se tornando aos poucos uma democracia. Em vista disso, a autora dialoga com os conceitos de democracia e autoritarismo, tendo como interlocutores autores como Robert Dahl e Guilhermo O’Donnell. Requião filiou-se ao PMDB, originário do antigo MDB (Movimento Democrático Brasileiro), partido de oposição consentida pelos próprios comandantes da ditadura militar em ter um papel contraposto ao partido de sustentação ao regime, a ARENA (Aliança Renovadora Nacional). Apesar de não ter a máquina do governo a seu favor, o MDB passou a obter resultados eleitorais muito satisfatórios, principalmente com as eleições de 1974. Com a redemocratização, o PMDB elegeu José Richa como governador do Paraná, derrotando o candidato do regime e das forças dominantes da ditadura, Saul Raiz. Roberto Requião, portanto, filiou-se a um partido que oferecia possibilidades de ascensão política no Paraná e também uma identidade ideológica de defesa da democracia e dos anseios em prol dos direitos humanos e de liberdade de expressão.

No capítulo 2, "Traços decisivos para a posição e ação política de Roberto Requião de Mello e Silva", Daiane Resende dedica-se em estudar a genealogia das famílias Mello e Silva e Requião, a partir de análises de Ricardo Costa de Oliveira sobre a família e as relações de parentesco de Requião, fundamentais para a compreensão da construção do seu habitus e dos seus capitais políticos. A autora percorre a sua biografia, desde o seu nascimento, passando pelos locais de estudo e trabalho, até a sua entrada na política, em 1982, quando eleito deputado estadual. Eleito prefeito de Curitiba em 1985, seus discursos chamam ainda mais atenção, dada a sua capacidade de oratória e a construção de sua imagem. Assim, a autora debate com teóricos do discurso e da mídia, como Jurgen Habermas, Hannah Arendt e Pierre Bourdieu. O próprio Requião se auto conclama "intelectual orgânico das classes populares" (p.89), e a partir disso a autora insere uma interessante discussão com a teoria do intelectual orgânico, formulada por Antônio Gramsci. Daiane Resende afirma que Requião não almeja o poder apenas por status ou dinheiro, mas sim também por questões ideológicas em prol do povo paranaense e brasileiro, pois sua maior ambição é chegar à presidência da república. Requião é produto de um contexto de redemocratização e de mudança nos traços autoritários e reprodutores das desigualdades sociais no país. Desta forma, Requião filia-se ao PMDB, partido no qual está filiado até hoje, e também defende as ideias da "Carta de Puebla", discurso do Papa João Paulo II, que defende a "opção preferencial pelos pobres" (p.95) e valorizar o público.

No capítulo 3 "Trajetória política de Roberto Requião de Mello e Silva”, Daiane Resende se dedica ao estudo da trajetória política de Requião a partir de 1982, quando eleito deputado estadual. Seu mandato foi caracterizado pela sua "independência, denúncia da corrupção e defesa dos interesses populares" (p.102). Em 1985, venceu Jaime Lerner na disputa para a Prefeitura de Curitiba, ocupando o cargo que seu pai, Wallace Thadeu de Mello e Silva, almejava alcançar no pleito de 1954, sendo derrotado por Ney Braga. Na prefeitura, Requião congelou os preços das tarifas de ônibus, implementou o vale-transporte, priorizou as 
políticas sociais aos mais pobres, instituiu a ouvidoria-geral da prefeitura junto a população, criou as subprefeituras junto aos conselhos comunitários e construiu um número notável de creches e postos de saúde na capital (p.105), além de implantar o "mercadão popular", oferecer assistência aos meninos de rua, realizar concursos públicos e reduzir a carga de trabalho no comércio e dos motoristas do transporte público em Curitiba. Após a prefeitura de Curitiba, Requião ocupou a Secretaria de Desenvolvimento Urbano no governo de seu colega de partido, Álvaro Dias, criando uma série de programas de planejamento no meio ambiente e da saúde, além da intensificação da polícia militar nos bairros junto à população. Em 1990, Requião sucedeu Álvaro Dias no governo do estado do Paraná, priorizando políticas sociais nas áreas de habitação, agricultura familiar, agroindústria, criação de empregos na indústria, diminuição dos conflitos agrários, recuperação dos mananciais do Paraná, formação dos trabalhadores e organização dos movimentos populares. Continuou seus projetos implementados no governo anterior na área de segurança pública, proibiu os bingos e estruturou a Secretaria de Estado da Justiça e Cidadania (SEJU). Também realizou trabalhos de destaque nas áreas de educação e no judiciário, negando aumentos aos juízes do Tribunal de Justiça. Em 1994, Requião foi eleito senador da república, destacando-se novamente pela sua oratória e polêmicas contra o seu partido, que apoiava algumas medidas do então presidente Fernando Henrique Cardoso. Em 2002 foi novamente eleito governador do Paraná, derrotando o seu ex-aliado político Álvaro Dias. Seu mandato foi caracterizado por políticas sociais de redução de tarifas da água e energia elétrica a famílias de baixa renda, além de programas habitacionais, piso salarial do estado, políticas nas áreas de segurança, cultura, educação, fechamento de bingos, diálogo com os movimentos sociais como o MST e o debate sobre os alimentos transgênicos e os pedágios no Paraná. Requião foi reeleito ao governo do estado do Paraná em 2006, derrotando Osmar Dias, irmão do já citado Álvaro Dias, com uma pequena margem de vantagem. Situação inédita no Paraná, pois Manoel Ribas governou o estado por três vezes como interventor indicado por Getúlio Vargas, não como governador eleito (p.145). Requião deu continuidade a suas políticas sociais realizadas no primeiro mandato. Visto as realizações e características de tais mandatos, Daiane Resende passa a analisar as redes políticas que Requião tece em seus mandatos no Executivo, pesquisando os titulares das pastas e secretarias dos seus governos, afirmando que o seu grupo político permanece praticamente o mesmo, assinalando também a prática de parentes ocupando cargos de confiança nos seus mandatos (p.156).

No capítulo 4 "Políticas Públicas e análise de um Perfil Econômico", Daiane Resende analisa as políticas públicas das gestões de Roberto Requião. Para isso, a autora se utiliza de autores como Adam Przeworski e suas reflexões sobre social-democracia, além de análises sobre o federalismo e a descentralização do Estado. Também discute os conceitos de cidadania e a relação entre as políticas de bemestar social em pleno ciclo neoliberal, intensificado na década de 1990. A autora assinala a inspiração social democrata das políticas de Requião nas suas gestões, remetendo-se a programas como o "Leite das Crianças" e estabelecendo um paralelo com as políticas sociais abordadas no capítulo 3. Resende enfatiza que Requião 
prioriza a descentralização econômica e a estatização no Estado, o que pode ser verificado nas suas políticas públicas no decorrer de suas gestões.

Vale ressaltar a qualidade do trabalho, bem fundamentado teórica e empiricamente. Daiane Resende analisa a trajetória social e política de Roberto Requião explorando uma boa quantidade de referências bibliográficas, além de fontes e discursos presentes nos anexos. Trata-se de um livro notável para a análise da política paranaense na atualidade. 